\title{
РАДІОТЕЛЕГРАФ УНР (1917-1921 рр.): ЗАРОДЖЕННЯ, ОСНОВНІ ХАРАКТЕРИСТИКИ, СТИЛЬОВІ ОСОБЛИВОСТІ
}

\author{
Майя Нагорняк \\ Інститут журналістики \\ Київського національного університету імені Тараса Шевченка, \\ вул. Юрія Іллєнка, 36/1, 04119, Київ, Україна \\ e-mail:mavanag@ukr.net \\ https://orcid.org/0000-0002-2197-1338
}

У статті розглянуто вагомий період становлення українського національного радіомовлення, який припав на пору проголошення й утвердження Української Народної Республіки (УНР) 1917-1921рр. Діяльність радіотелеграфу та радіозв'язку, здійснювана урядом УНР в особі Міністерства Пошт і Телеграфів, ознаменувалася виробництвом первинного радіоконтенту. Його вважаємо прообразом сучасних інформаційних радіоповідомлень. Публікацію підготовлено на основі опрацьованих архівних матеріалів періоду УНР Центрального державного архіву вищих органів влади та управління України.

Ключові слова: радіотелеграф, радіозв'язок, радіотелеграфний контент, інформаційне повідомлення.

Актуальність. Історія українського національного радіомовлення традиційно провадить свій відлік від 20-х років XX століття. Для журналістикознавців відправною точкою була та лишається дата 16 листопада 1924 року, коли у Харкові в ефір вийшла перша радіопередача. Дослідники радянського періоду акцентують увагу на широкому використанні можливостей радіо більшовицькою партією на чолі із B.I.Леніним. Натомість, історичний період, що передує означеним межам, а саме 1917-1921 роки, жодним чином не відображений у працях учених. Означений час $\epsilon$ надто вагомим у процесах становлення і розвитку українського національного радіомовлення зокрема та Української держави загалом.

Ясна річ, що говорити про тогочасне регулярне радіомовлення у загальноприйнятому розумінні цих слів, було б перебільшенням. Однак, привертає увагу той факт, що уряд Української Народної Республіки напрочуд активно використовував потужності, які з'явилися із появою радіотелеграфу та радіозв'язку. Саме завдяки новим технологічним явищам XX ст. молода Українська держава здійснювала відчайдушні спроби розв'язувати проблеми, зумовлені ії функціонуванням як усередині країни, так і ззовні. Численні архівні документи тієї доби дають можливість змінити точку зору щодо початку діяльності вітчизняного радіомовлення, усвідомити непе-

(C) Нагорняк М., 2019

Наукове рецензування і рекомендація до друку - проф. Кость С. А. 
ресічність ролі й місця радіотелеграфу та радіозв’язку в буремних суспільно-політичних подіях 1917-1921 років.

Новизна проблеми (аспекту). Опрацювання архівних даних, пов’язаних із активною діяльністю уряду УНР, вивчення матеріалів листування, яке провадилося державниками як між міністерствами, відомствами, громадськими інституціями республіки, так і з урядами закордонних країн, дозволяє трактувати місію радіо як місію виключно державницьку, суспільно будівничу. Власне, саме цей суперечливий історичний період поклав початок розумінню правдивої ролі нового засобу зв'язку в еволюційних процесах становлення України на мапах Європи другого десятиліття ХХ століття.

Задля здійснення ефективних комунікацій - як внутрішніх, так і зовнішніх держава конче потребувала якісної й досконалої системи спілкування, яка б дозволяла здійснювати оперативну передачу урядового новинного контенту. Виконавчий орган влади в УНР Рада народних міністрів у січні 1918 р. створила Міністерство Пошт і Телеграфів (всі слова написано з великої літери відповідно до документів авт.). До цього відомства стікалася величезна кількість суспільно значущої політичної, соціально-економічної, міжнародної інформації, яку необхідно було якомога швидше направляти до усіх інших міністерств УНР, а також до закордонних відомств країн світу. Відповідні службові пересилання здійснювалися завдяки системі радіозв'язку та радіотелеграфу. При цьому, численні розпорядження, накази, виступи, пояснювальні записки тощо доцільно розглядати як найперші форми новинної радіоінформації.

Огляд літератури. В історії українського журналістикознавства загалом та історії українського радіомовлення зокрема питання контенту доби УНР не вивчалося, здебільшого, через ідеологічні причини. Тривалий час 20-і роки XX ст. в історії Українського радіо вивчалися із позицій жовтневого перевороту, діяльності радянської влади й більшовиків на чолі із В.І.Леніним. Контент радіо, який супроводжував згадані події, докладно розглядався радянськими й українськими дослідниками радіокомунікацій. Йдеться про праці В.М.Ружникова, Е.Г.Багірова, В.Б.Дубровіна, П.С.Гуревича, Ю.В.Летунова, І.Г.Мащенка, В.Я.Миронченка, М.І.Прокопенка та інших.

3 огляду на зазначене вище, метою даного дослідження є довести, що радіотелеграфний контент УНР 1917-1921 рр. став прообразом сучасної радіоінформаціїі. Серед завдань виокреслюємо такі: з'ясувати, як відбулося зародження радіотелеграфного контенту; визначити його основні характеристики; вивчити стильові особливості, що слугували піднесенню ефективності відомостей.

Одержані результати. Задля кращого розуміння ситуації, в якій опинилася Україна в другому десятилітті XX ст., зробімо невеликий екскурс в історію. Напрочуд влучно охарактеризував цей стан тогочасний ідеолог українознавчих процесів М.Грушевський, назвавши його «станом великої Руїни». Імперські амбіції Росії у Першій світовій війні полягали в тому, аби якомога скорше покінчити з українським визвольним рухом. Польща прагнула заселити спорожнілі землі України, тим самим посиливши свою територіальну присутність у світі. Давалася взнаки і мінлива політика Австро-Угорщини з її різними політичними угрупованнями у владі. Великі політичні гравці відводили Україні виключно роль буферної зони між Австро-Угорщиною та Росією. Внаслідок цього, вкраїнські землі розподілялися на три частини - 
одна мала лишатися у складі Австро-Угорщини, друга стати територією Польщі і третя - формально незалежна - розглядалася як «сіра зона» $[1,199]$.

Українські державники усвідомлювали небезпеку, яка виходила від згаданих країн, і були переконані в тім, що необхідно створювати власну модель майбутньої Української держави. Однак, зреалізувати цю ідею було напрочуд складно, оскільки на рівні масової свідомості ситуація була ще гіршою і заплутанішою. Народ перебував у розпачливому стані, бо не розумів сенсу безкінечних кривавих боїв Першої світової. Більшовицький переворот у Петрограді ще більше дезорієнтував українців. Але, незважаючи ні на що, зазначають історики, війна створила умови артикуляції ідеї української незалежності та її донесення до європейської політичної свідомості.

3 огляду на це, виглядає логічним і доречним той факт, що 7 листопада 1917 року на засіданні Малої ради Української Центральної Ради М. Грушевський уперше поставив питання про проголошення Української Народної Республіки. Він зауважив, що в момент відсутності центральної влади, розпалу громадянської війни, щоб боронити здобутки України, треба мати міцну підвалину і такою підвалиною може бути тільки проголошення Української Народної Республіки. Після чого зачитали Універсал, згідно з яким проголошувалося створення УНР у федеративному зв'язку з Російською державою. Виконавчим органом влади в УНР стала Рада народних міністрів [1,218].

Звертаємо особливу увагу га те, що одним із перших кроків уряду УНР було створення Міністерства Пошт і Телеграфів. Архітектори української державності усвідомлювали, що без системи добре налагодженого зв'язку між суб'єктами влади та господарювання у самій країні та поза ії межами створення і подальше функціонування моделі держави приречене на загибель. Міністром Пошт і Телеграфів України уряду Володимира Винниченка (січень 1918 р.) став Микита Шаповал. Будучи соціологом, публіцистом і поетом, він розумів, що злагоджена робота радіотелеграфу означатиме набуття великого авторитету УНР і в Україні, і у світі.

Життедіяльність УНР від самих початків базувалася на необхідності використання української мови як єдиної державної. У зв’язку з цим не можна оминути такого документа, як «Наказ про вживання в слові і пісьмі Державноі Українськоі мови по Поштово-Телеграфному відомству Міністра Внутрішніх Справ по Поштово-Телеграфному відомству. м.Київ, 26 липня 1918 р. № 81». Зауважимо, що документ в обов'язковому порядку був розісланий радіотелеграфом в усі міністерства, відомства, інші суспільні інституції. Стилістика збережена: «В Українській Незалежній Самостійній Державі державною мовою визнаеться мова українська. Зважаючи на се, наказую Начальникам Округ звернути особливу увагу, щоб співробітники Вiдомства на пошті і телеграфі, радіотелеграфі і телефоні при виконанні службових обов'язків вживали лише української мови і вжити всіх заходів при зносинах по всіх службових справах зо всіма державними і приватними установами, а також урядовими особами переписку провадити виключно державною мовою; звернути також увагу, що коли в Відомстві ще е співробітники, які до сього часу не володіють українською мовою, щоб вони поважно подбали про швидче ії вивчення.

Нові співробітники, які будуть призначатися на посади по Відомству, мусять володіти як в слові, так і в пісьмі державною мовою. За Міністра Внутрішніх Справ Кулябко-Корецький (підпис)» $[2,188]$. 
Утвердження Української Народної Республіки гостро потребувало відкритого поширення фактів, поглядів, коментарів задля формування громадської думки про події внутрішнього та зовнішнього життя, а також із метою недопущення провокативної, недостовірної інформації про Україну в світі. 3 огляду на це, фактично через рік після проголошення УНР, 26 грудня 1918 року, в уряді Володимира Чехівського було створено такий важливий підрозділ, як Міністерство преси та пропаганди.

У Міністерстві діяв спеціальний Відділ преси, який працював у сфері інформування української спільноти, а також української еміграції, яка перебувала на території Польщі, про боротьбу українського народу за свої права та 3 ворожим для нього впливом більшовицької Росії. Це здійснювалося шляхом систематичного розміщення у всіх закордонних газетах інформації про події в Україні. Пресовий відділ створив власний друкований орган, який інформував спільноту про діяльність УНР, а також зорганізовував українське громадянство на Волині та Холмщині. Такою трибуною став «УКРАІНПРЕС». Задля залучення громадян означених регіонів до орбіти впливів УНР всі матеріали надсилалися також і українським Просвітам у Рівному, Луцьку, Ковелі, Кременці, Володимирі-Волинському та Хелмі. Але головна робота органу буда зосереджена на формування закордонної опінії про Україну.

У зв'язку з цим щодня випускалися інформаційні обіжники (огляди - авт.), які надсилалися у всі українські, польські і навіть російські газети. Зауважмо, що майже всі видання, які отримували обіжники, бодай частково, але вміщували їх на своїх шпальтах. Але були й такі, які на постійній основі повною мірою передруковували матеріали «УКРАІНПРЕСу». До цих видань належали українські газети «Воля», «Рідний край», «Син України», «Українське слово».

Підготовка обіжників виданням «УКРАІНПРЕС», в яких детально йшлося про події з усіх сфер життя УНР, була вагомим кроком на шляху до здійснення цілеспрямованої й ефективної комунікації між українською спільнотою всередині країни та закордонними осередками українців. Це також був один зі способів налагодження дійової співпраці з урядами держав, які підтримували УНР. Крім того, продукування контенту для газет слід розглядати як передумову для його передачі каналами телеграфу, який навіть у ті часи був значно оперативнішим засобом донесення інформації, аніж друковані видання.

Зважаючи на цю обставину, не можна не звернути увагу на один вельми переконливий фрагмент Огляду діяльності Міністерства преси та пропаганди від 1 серпня до 1 листопада 1921 року, вміщений у розділі «Пропаганда». Йдеться про те, що посол Яковлев (немає докладних даних про нього - авт.) пише у звіті: «...безумовно необхідно, щоб «УКРАІНПРЕС» постачав матеріяли для пропаганди й щоб цей матеріял доходив до нас, якнайшвідче був точний і перевірений, а також відповідав часу... бажано надсилку більш цікавого матеріялу робити телеграфом, а инший більш широкий матеріял треба надсилати що-дня, або через день» [3, 37].

Власне, думка, висловлена послом Яковлевим щодо використання телеграфу, доводить незаперечний факт - серед прогресивно налаштованих офіційних чинників (дипломатів, урядовців, працівників державних інституцій та ін.) існувало усвідомлення того, що задля прориву інформаційної блокади УНР необхідно використовувати більш потужні та оперативні засоби масової комунікації, аніж газети та інформаційні агенції. Неабияке значення мав і диференційований підхід у відборі інформації, адже пропонувалося використовувати телеграф лише для розсилки 
особливо важливих, цікавих відомостей. Із цього доходимо висновку, що питанню надання громадянам суспільновагомої інформації про діяльність УНР приділялося багато уваги.

Справа інформування в УНР була налагоджена доволі добре, оскільки всі ключові й важливі суспільні події знаходили миттєве відображення у листуванні між міністерствами та відомствами. Так, документом історичного значення є лист Міністерства Закордонних Справ до Міністерства Пошт і Телеграфів від 02.06.1920 p. про звільнення України від більшовицької влади. Це документ такого змісту: «До Міністерства Пошт і Телеграфів У.Н.Р.. Департамент Поштовий, Відділ Міжнародний. 3 доручення п. Міністра Закордонних Справ Департамент Чужоземних Зносин М.3.С. у відповідь на Ваше письмо від 28/V ц.р. за ч. 1029 мае честь повідомити, що вся теріторія Украіни звільнена від большовиків на протязі часу починаючи від 25/ IV ц.р. мае цивільну адміністрацію украінську. На тій території можна встановляти поштово-телеграфні установи і налагоджувати поштово-телеграфний зв'язок. Директор Департамету Чужоземних Зносин Шкільний (підпис нерозбірливо)» $[4,6]$.

Той факт, що після повідомлення про звільнення території України від більшовиків пропонується негайно встановити поштово-телеграфний зв’язок, переконливо доводить, яку величезну роль відводили очільники держави масовому інформуванню спільноти. Питання передачі інформації на відстань у межах країни, а також на закордонні терени набуло першорядної ваги. Саме цим можна пояснити лист Міністерства Пошт і Телеграфів до Пана Губерніяльного Комісара Поділля від 01.06.1920 p. із проханням в екстренному порядку шукати телеграфне майно, яке могло залишитися від більшовиків: «Як відомо з певних джерел, в районі Жмеринки і в самій Жмеринці переховується, в приватніх руках багато Державного телеграфно-телефонного і радіотелеграфного майна, розграбованого при військових подіях. Прошу не відмовити в розпорядженні, аби там було проізведено труси по крамницям і помешканням і якщо буде найдено вище згадане майно, то повернути його п.т. відомству, де зараз в ньому великий брак. Директор Технічного Департаменту Бутенко. Начальник Телеграфного Відділу Дашкевич (підписи)». Стилістику збережено [4, 7].

На нагальній необхідності встановити поштово-телеграфне сполучення між УНР та іншими державами світу повсякчас наголошувало Міністерство Закордонних Справ. Привертає увагу лист тимчасового виконувача обов'язків Голови Торгово-економічної Дипльоматичної Місії в Річі Посполитій Польській Фещенка-Чопівського до Міністра Пошт і Телеграфів У.Н.Р.: «Гадаю, що немає потреби пояснювати докладно, яке величезне значіння мае систематичне, організоване поштово-телеграфне сполучення урядових інституцій і приватного населення У.Н.Р. з закордоном, а особливо в той час, коли розпочнуться економичні зносини між У.Н.Р. і Европейськими державами. Тому дозволю собі взяти ініціятиву в справі піднесення перед Вами, Високоповажаний Пане Міністре, дуже важливого питання про улаштування поштово-телеграфного сполучення між У.Н.Р. і Державами Західньоі Европи при посередництві Річі Посполитоі Польськоі. Для сього було б бажано чи надіслати Ваших уповноважених представників до Польського Уряду, чи доручити цю справу перебуваючому в складі Варшавськоі Місіі Віце-Міністра Шляхів Лукашевичу, надіславши до нього відповідних фахівців довіреного Вам Міністерства для вироблення умов по порозумінню з польськими представниками. Всю цю справу бажано було б налагодити негайно, не чекаючи завірення сталоі поштово-телеграфноі конвенціі 
між Украіною та Польщею. Таку ж саме справу було б бажано налагодити і в Румуніi. Тимчасовий виконувач обов'язків Голови Торгово-економічної Дипльоматичної Місії в Річі Посполитій Польській Фещенко-Чопівський. Віце-Міністр Шляхів Лукашевич». Стилістику збережено. [5, 4].

Відчайдушні пошуки уряду шляхів щодо встановлення комунікацій як усередині країни, так і поза її межами мають неоціненне значення для історії України, адже вони засвідчують глибоке прагнення державних достойників часів УНР будувати міцну й потужну державу.

Зауважмо, всі зазначені документи розсилалися у профільні міністерства й відомства шляхом радіотелеграфу та радіозв'язку. Себто урядовий новинний контент мав три прояви - епістолярний (надсилання новин у вигляді листів), газетний (оприлюднення новин у друкованих виданнях) і радіотелеграфний (поширення відомостей за допомогою дротів). Останній вид контенту був найпріоритетнішим, найзручнішим, бо передача новинної інформації здійснювалась практично миттєво.

Таким чином, проаналізувавши радіотелеграфний контент, визначаємо його основні ознаки та стильові особливості:

- використання офіційно-ділового стилю як єдино можливої форми донесення інформації (накази, розпорядження, вказівки тощо);

- застосування елементів епістолярного стилю задля посилення сприйняття повідомлень;

- наснаженість пропагандистською риторикою;

- розлогість змістової частини;

- відсутність структурно-композиційних елементів;

- перенасичення суспільно-політичною лексикою;

- надмірне використання складних синтаксичних конструкцій; зловживання віддієслівними іменниками, дієсловами умовного способу;

- використання канцеляризмів, штампів, кліше тощо.

Висновки. Радіотелеграфний контент Української Народної Республіки періоду 1917-1921 рр. став першим інформаційним продуктом діяльності молодої країни. Завдяки продукуванню цього контенту було здійснено перші кроки із забезпечення вітчизняних і закордонних інституцій, спільнот достовірною, правдивою, вичерпною інформацією про буремні події першої світової війни та повоєнних років. На жаль, розбурханість, суперечливість політичних процесів на теренах України, зумовлених першою світовою війною та боротьбою із їі наслідками, жовтневим переворотом у Петрограді, проголошенням й утвердженням УНР, катастрофічно низьким рівнем економіки, позбавляли радіозв'язок та радіотелеграф стрімкого розвитку. Однак, незважаючи на несприятливу суспільно-політичну ситуацію, вони напрочуд ефективно прислужилися тогочасним викликам. Ключову роль відіграло те, що очільники УНР, мислячи державними масштабами, чітко розуміли, що задля всебічної підтримки ідеї незалежної України з боку української та зарубіжної спільнот винятково важливо мати неупереджену інформацію про події, що відбуваються. Поширення вагомої суспільно-політичної інформації засобами радіотелеграфу та радіозв'язку вважалося стратегічним завданням держави, через що на нові засоби комунікації покладалися особливі сподівання.

Основні ознаки радіотелеграфного контенту значною мірою зумовлювалися наслідуванням друкованих видань, що виглядало цілком природним, оскільки ніяких 
інших засобів інформації й комунікації у той час не існувало. Тож, недарма дослідники радіо називають цей період розвитку учнівським - радіотелеграф був своєрідним учнем газети. Однак, копіювання газет мало свої як позитивні, так і негативні сторони. Серед позитивів $є$ те, що, спираючись на досвід газет, радіотелеграф напрацьовував свої стандарти подачі інформації, хоч і робив це надто поволі. До негативів відносимо надмірне захоплення газетою та неможливість вийти із ії тіні.

Стильові ознаки радіотелеграфного контенту, відповідно, повною мірою відображали ознаки контенту газети, контентів офіційних документів і усних розпоряджень.

Пройшовши довготривалий і болісний шлях свого становлення, радіотелеграфний контент періоду УНР 1917-1921 років у подальшому зумів виробити суто радійні методи і прийоми подачі інформації, які не могли не позначитися на якості та ефективності надання спільноті вагомих і необхідних суспільнозначущих відомостей.

\section{REFERENCES}

1. Україна: політична історія. XX - початок XXI ст. / Редрада: В.М.Литвин (голова) та ін. Редкол.: В.А.Смолій, Ю.А.Левенець (співголови) та ін. К.: Парламентське вид-во, 2007. $1028 \mathrm{c.}$

2. Центральний державний архів вищих органів влади та управління України. Ф №2592, опис № 1, справа № 10.

3. Центральний державний архів вищих органів влади та управління України. Ф №1113, опис № 2, справа № 222, 8 квітня 1921 р.

4. Центральний державний архів вищих органів влади та управління України. Ф №554, опис № 1, справа № 175.

5. Центральний державний архів вищих органів влади та управління України. Ф №554, опис № 1, справа № 174. 


\title{
RADIOTELEGRAPHIC CONTENT OF UNR (1917-1921): ORIGIN, MAIN CHARACTERISTICS, STYLE FEATURES
}

\author{
Maya Nahorniak \\ Institute of Journalism Taras Shevchenko National University of Kyiv \\ Yuriia Illienka str., 36/1, 04119, Kyiv, Ukraine \\ e-mail: mayanag@ukr.net \\ https://orcid.org/0000-0002-2197-1338
}

The article deals with the significant period of Ukrainian national radio broadcasting, which occurred at the time of the proclamation and approval of the Ukrainian People's Republic (UNR) in 1917-1921. The activity of radiotelegraphic and radio communications, carried out by the Government of the UNR in the person of the Post and Telegraph Ministry, was marked by the production of primary radio content. We consider it the prototype of modern information radio messages. The publication is prepared on the basis of the processed archival materials of the UNR period of the Central State Archives of the Supreme Governments and Governments of Ukraine.

The author came to the conclusion that the Radiotelegraphic content of the Ukrainian People's Republic from 1917-1921 was the first information product of a young country. Thanks to the production of this content, the first steps have been taken to ensure that domestic and foreign institutions, communities have reliable, truthful, comprehensive information on the turbulent events of the First World War and post-war years.

It is suggested that due to the turbulence, the contradictory nature of political processes in Ukraine, caused by the First World War and the struggle against its consequences, the October coup in Petrograd, the proclamation and approval of the UNR, a catastrophically low level of economics, deprived of radio communication and wireless technology of rapid development. However, in spite of the unfavorable social-political situation, radiotelegraphy and radio communications surprisingly and efficiently served the challenges of the day. The dissemination of significant social-political information by means of radiotelegraph and radio was considered a strategic task of the state, which led to special hopes for new means of communication.

Key words: radiotelegraph, radiocommunication, radiotelegraphic content, informational message. 